\title{
MARIE GIGAULT DE BELLEFONDS, AMBASSADRESS OF FRANCE. GENDER, POWER AND DIPLOMACY AT THE COURT OF CHARLES II OF SPAIN, 1679-1681.
}

\author{
Ezequiel Borgognoni \\ (Universidad de los Andes, Chile) \\ eborgognoni@gmail.com
}

\begin{abstract}
In this article, I will analyse the political activity of marquise Marie Gigault de Bellefonds, ambassadress of France at the Madrid court between 1679 and 1681, by reflecting on the different diplomatic strategies implemented by her and her husband in order to gain the favour of the monarchs, particularly of the queen consort MarieLouise of Orleans. The study of Louis XIV of France's instructions to his ambassador and the perusal of the letters that the ambassadress sent to her friends in Paris evidence the importance of collaborative work in the marriages among diplomats in seventeenth-century court society. Moreover, our sources allow us to make visible the role of the wives of ambassadors in the pre-modern diplomatic system - a field of study in its beginning stages, but also highly promising.

Who was Marie Gigault de Bellefonds? Why was she considered a dangerous individual or, as stated by Saint-Simon, «evil as a snake» at the court? Who were her main adversaries in Madrid? What was she accused of? Why did she and her husband have to leave the embassy in 1681? This research will attempt to answer these and other questions related to the presence of the French ambassadress at the court of Charles II and Marie-Louise of Orleans.
\end{abstract}

KEY WORDS: Gender; diplomacy; French embassy; Spanish monarchy; seventeenth century.

This work is part of a Fondecyt post-doctoral project $\mathrm{N}^{\circ}$ 3190305, and the author would like to thank Fondecyt Program for its financial support. 


\section{MARIE GIGAULT DE BELLEFONDS, EMBAJADORA DE FRANCIA. GÉNERO, PODER Y DIPLOMACIA EN LA CORTE DE CARLOS II DE ESPAÑA, 1679-1681}

\section{RESUMEN}

En este artículo analizaré la actividad política de la marquesa Marie Gigault de Bellefons, embajadora de Francia en la corte de Madrid entre 1679 y 1681, a través de la reflexión de las distintas estrategias diplomáticas instrumentadas por ella y su esposo para ganar el favor de los reyes, en particular de la reina consorte María Luisa de Orleans. El estudio de las instrucciones de Luis XIV de Francia a su embajador y el análisis de las cartas que la embajadora envío a una de sus amigas parisinas ponen en evidencia la importancia del trabajo colaborativo en los matrimonios entre diplomáticos en la sociedad cortesana del siglo XVII. Además, nuestras fuentes nos permiten visibilizar el rol de las esposas de los embajadores en el sistema diplomático pre-moderno, un campo de investigación en estado germinal pero con un enorme potencial.

¿Quién era Marie Gigault de Bellefons? ¿Por qué era considera un personaje peligroso o, como apunta Saint Simón, «malvada como una serpiente» en la corte? ¿Quiénes eran sus principales adversarios en Madrid? ¿De qué fue acusada? ¿Por qué ella y su marido debieron abandonar la embajada en 1681? A lo largo de esta investigación, intentaremos dar respuesta a estos y otros interrogantes vinculados a la presencia de la embajadora de Francia en la corte de Carlos II y María Luisa de Orleans.

PALABRAS CLAVES: Género; diplomacia; embajada francesa; monarquía hispana; siglo XVII.

\section{INTRODUCTION}

In recent decades, the rise of gender studies has influenced historiographical production in relation to diplomatic and foreign relations history. The inclusion of the gender dimension has promoted something beyond renovation in a field that had been strongly influenced by nineteenth-century ideologies. More than a few specialists assert that they are aiding in the construction of a new diplomatic history that provides with more appropriate answers to the challenges and questions of 
postmodern society ${ }^{1}$. In a thought-provoking article titled "Toward a New Diplomatic History of Medieval and Early Modern Europe", John Watkins has acknowledged the importance of gender studies to understand the diplomatic culture of the pre-modern world ${ }^{2}$. Recently, Glenda Sluga and Carolyn James have evidenced that, ever since the Renaissance origins of diplomacy, women were political and cultural agents, they intervened in the formation of alliances, performed as negotiators and built transnational power networks ${ }^{3}$. The works published in the volume edited by Corina Bastian, Eva Kathrin Dade, Hillard von Thiessen and Christian Windler reinforce these hypotheses ${ }^{4}$. In the Ancien Régime, the lack of separation between the public and the private, the importance of power networks, the functioning of a clientelist system, and the role of married couples as work couples (Arbeitspaar) contributed to the inclusion of women in the international political system ${ }^{5}$.

Historiography has evidenced that queens and princesses performed an active role in diplomatic circles or court society ${ }^{6}$. However, the political activity of the ambassadors' wives is less known. Since the late sixteenth century, the ambassadors' wives received the title of "ambassadresses", a term that is frequently repeated in seventeenth- and eighteenth-century documents. The ambassadresses created new spaces for action and negotiation within the court structure that allowed them to influence the monarchs. The ultimate goal of the ambassadresses' actions was to get the trust of the queen and establish a friendship that could ensure the objectives of their husbands' diplomatic mission. Therefore, in this text, I seek to analyze Marie

\footnotetext{
${ }^{1}$ Karin Aggestam and Ann Towns, "The gender turn in diplomacy: a new research agenda," International Feminist Journal of Politics $21 \quad$ (2019), https://www.tandfonline.com/doi/full/10.1080/14616742.2018.1483206 (accessed 25th October 2019). Jennifer Cassidy, ed., Gender and Diplomacy (London and New York: Routledge, 2018). David Reynols, "International History, the Cultural Turn and the Diplomatic Twitch," Cultural and Social History 3 (2006), https://www.tandfonline.com/doi/abs/10.1191/1478003806cs053xx (accessed 25th October 2019).

${ }^{2}$ John Watkins, "Toward a New Diplomatic History of Medieval and Early Modern Europe," Journal of Medieval and Early Modern Studies 38/1 (2008), https://read.dukeupress.edu/jmems/article/38/1/1/1026/Toward-a-New-Diplomatic-History-ofMedieval-and (accessed October 25, 2019).

${ }^{3}$ Glenda Sluga and Carolyn James, eds., Women, Diplomacy and International Politics since 1500 (London: Routledge, 2015).

${ }^{4}$ Corina Bastian, Eva Kathrin Dade, Hillard von Thiessen and Christian Windler, eds., Das Geschlecht der Diplomatie. Geschlechterrollen in den Außenbeziehungen vom Spätmittelalter bis zum 20. Jabrbundert (Köln: Böhlau, 2014).

${ }^{5}$ Katrin Keller. "Frauen-Hof_Diplomatie: Die höfische Gesellschaft als Handlungsraum von Frauen in Außenbeziehungen," in Das Geschlecht der Diplomatie. Geschlechterrollen in den Außenbeziebungen vom Spätmittelalter bis zum 20. Jabrbundert, eds. Corina Bastian, Eva Kathrin Dade, Hillard von Thiessen and Christian Windler (Köln: Böhlau, 2014), 33-50. Olwen Hufton, "Reflections on the Role of Women in the Early Modern Court," The Court Historian 5/1 (2000), https://www.tandfonline.com/doi/abs/10.1179/cou.2000.5.1.001 (accessed October 25, 2019)

${ }^{6}$ Clarissa Campbell Orr, ed., Queenship in Europe, 1660-1815: The Role of the Consort (Cambridge: Cambridge University Press, 2004).

${ }^{7}$ Carl von Friedrich Moser, L'ambassadrice et ses droits (Berlín : Étienne de Bourdeaux, 1754).
} 
Gigault de Bellefonds' political activity as French ambassadress at the court in Madrid between 1679 and 1681 by reflecting on the different diplomatic strategies implemented by her and her husband in order to gain the favour of the monarchs, particularly that of the queen consort Marie-Louise of Orleans.

The studies on ambassadresses' political roles in European courts in the seventeenth century are still at an early stage and, hence, are highly promising. One of the pioneering pieces of research is written by Alain Hugon, who very early noted marquise Francisca de Zúñiga y Dávila's political activity during her husband's trip to Brussels. He was the Spanish ambassador in Louis XIII's France. The affective bond that the Spanish ambassadress established with queen Anne of Austria allowed her some political and ceremonial benefits ${ }^{8}$. At the same time, in Madrid, the French ambassadress - marquise du Fargis- managed to influence Queen Isabel of Bourbon to convince King Philip IV to sign the peace treaty over the Valtellina'. Today, the works by Laura Oliván constitute a compulsory reference to consider the role of imperial ambassadresses in the courts of Philip IV and Charles II. On the one hand, she has specialized in the diplomatic missions of Maria Sophia von Dietrichstein and Johanna Theresia Lamberg at the Madrid court between 1663 and 1675. Likewise, she has referred to the diplomatic role of Lady Fanshaw, wife of the English ambassador at the courts in Lisbon and Madrid, starting from a study of her memoirs $^{10}$. Finally, it is important to note Ana Álvarez López's work, as she has studied the role of Marie Anne Claude Brulart, wife of the marquis d'Harcourt and ambassador of Louis XIV, in her husband's diplomatic mission at the court of Charles II in 1698. In the context of the later conflict following the death of the monarch, marquise d'Harcourt jointly worked with her husband in order to gain sympathizers for the French cause:

The role marquise d'Harcourt performed in her husband's mission perfectly illustrates the participation of ambassadresses in diplomatic missions. Key elements of court sociability, the ladies could be not only sources of information for an ambassador, but also means for frequent communication with noted members of the court, children, husbands, parents and siblings. This made it convenient to appreciate and relate with them as much as possible, always within the rules of honest trade. This was where their wives could make their jobs significantly easier. On the other hand, it was equally important to gain the favour of the queens, particularly the sovereign, both because it was evidently convenient to ingratiate themselves with the

8 Alain Hugon, Au service du roi catholique: «Honorables ambassadeurs » et «divins espions ». Représentation diplomatique et service secret dans les relations hispano-françaises de 1598 à 1635 (Madrid : Casa de Velázquez, 2004).

9 Jean François Dubost, Marie de Médicis. La reine dévoilée (Paris : Biographie Payot, 2011).

${ }^{10}$ Laura Oliván, "Gender, Work and Diplomacy in Baroque Spain : The Ambassadorial Couples of the Holy Roman Empire as Arbeitspaare," Gender \& History, 29/2 (2017), https://onlinelibrary.wiley.com/doi/abs/10.1111/1468-0424.12290 (accessed 26 October 2019). Ibídem. "Lady Anne Fanshawe, ambassadress of England at the Court of Madrid (1664-1666)," in Women, Diplomacy and International Politics since 1500, eds. Glenda Sluga and Carolyn James (London: Routledge, 2015), 68-85. 
most relevant personalities of the court and, as we shall see later, because one of their strategies was to have an indirect influence on prominent figures of difficult access through those close to them ${ }^{11}$.

In the pre-industrial world, married couples worked cooperatively with the purpose of achieving a specific objective. Heide Wunder has proposed the concept of Arbeitspaare (working couple) to underscore the collaborative nature of the work in the context of family economies ${ }^{12}$. In the last five years, noted specialists on gender and diplomacy have applied this concept to the study of royal and noble couples of the Ancien Régime ${ }^{13}$. Recently, Oliván has stressed the usefulness of applying the terms 'work' and 'working couple' in reference to the collaborative strategies of the ambassador and his wife with the purpose of achieving a specific diplomatic mission $^{14}$. This research will attempt to demonstrate that the French ambassador and his wife worked side by side in Madrid between 1679 and 1681 for the benefit of Louis XIV's pretensions. The instructions from Louis XIV to his ambassador and the ambassadress' letters to her friends in Paris not only show the couple's joint effort, but also the great extent of political activism by the ambassadress who, after establishing a close friendship with the queen, became a figure with the same or even more power than her husband.

\section{MARIE GIGAULT DE BELLEFONDS: AN AGENT OF FRENCH POWER AT THE COURT OF CHARLES II}

Marie Gigault de Bellefonds was born in Paris in 1624. She was the daughter of marquis Bernardin Gigault de Bellefonds, Governor of Valognes and of the village

\footnotetext{
11 All of the translations from the original Spanish to English are mine. «El papel que la marquesa d'Harcourt desempeñó en la misión de su marido ilustra perfectamente la participación de las embajadoras en las misiones diplomáticas. Elementos claves de la sociabilidad cortesana, las damas podían ser para un embajador no sólo fuentes de información sino medios de trato asiduo con los notables de la corte, hijos, maridos, padres y hermanos. Por eso convenía hacerse apreciar y relacionarse con ellas lo máximo posible, siempre dentro de las reglas del comercio honesto. Ahí era donde sus esposas podían facilitarles enormemente el trabajo. Por otra parte era igualmente importante obtener el favor de las reinas, sobre todo la reinante. No sólo porque evidentemente convenía congraciarse con las personalidades más relevantes de la corte, sino porque como veremos más tarde uno de sus instrumentos de acción era actuar sobre notables de acceso difícil indirectamente, a través de sus más allegados». In Ana Álvarez López, "Los negocios de Luis XIV en Madrid," Revista de Historia Moderna 25 (2007), https://revistahistoriamoderna.ua.es/article/view/2007-n25-losnegocios-de-luis-xiv-en-madrid-la-accion-de-sus-embajadores-en-la-corte-madrilena (accessed, 28th October 2019), 188.

${ }^{12}$ Heide Wunder, He is the Sun. She is the Moon: Women in Early Modern Germany (Cambridge: Cambridge University Press, 1988).

13 Katrin Keller. "Ladies-in-waiting at the Imperial Court of Vienna from 1550 to 1700: structures, responsibilities, and career patterns," in The Politics of Female Households. Ladies-in-waiting across Early Modern Europe, eds. Nadine Akkerman and Birgit Houben (Leiden-Boston: Brill, 2014), 77-97. Judith Aikin, A Ruler's Consort in Early Modern Germany: Aemilia Juliana of Schwarzburg-Rudolstadt (Farnham: Ashgate, 2014), 101-136.

14 Oliván, "Gender, Work and Diplomacy", 425-426.
} 
and castle of Caen, and Jeanne Suzanne aux Épaules ${ }^{15}$. She had a brother, Henri Robert, and six sisters: Jeanne, Françoise, Eléonore, Laurence, Judith, and Madeleine $^{16}$. On $24^{\text {th }}$ January 1651, she married marquis Pierre de Villars, Lord of La Chapelle, gentleman to the Prince of Conti, Lieutenant General and, later, ambassador of King Louis XIV of France at the courts of Copenhagen, Turin and Madrid $^{17}$. Although the Villars and their children had a hectic and itinerant life, the family stayed together because the marquis generally moved with his wife and offspring.

During their stays abroad, the marquise exchanged a numerous amount of letters with her friends. At the time, as Antonio Castillo Gómez states, it was extremely difficult to imagine life without letters ${ }^{18}$. We believe that the analysis of this type of source is key for understanding pre-modern diplomatic culture. The possibilities given by the epistles have been credited by several specialists. José María Imízcoz Beunza and Lara Arroyo Ruiz, applying "Social Network Analysis" parameters and methods, have underscored that private correspondence is the only documentary source that reveals direct interactions, not institutionally mediated, among social actors ${ }^{19}$. Fernando Bouza, Pedro Cardim and Paola Volpini have discussed the important question of the role letters had in European sixteenth- and seventeenth-century international diplomacy, emphasizing that they are an indispensable source for the study of diplomacy from an interdisciplinary viewpoint ${ }^{20}$.

${ }^{15}$ Ferdinand Hoefer, Nouvelle Biographie Générale, t. 45 (Paris : Firmin-Didot, 1866), 167. Vicente Díez Canseco, Diccionario Biográfico Universal de Mujeres Célebres, t. 3 (Madrid: Imprenta de D. José Félix Palacios, 1845), 622-23. Louis Gabriel Michaud, Biographie Universelle Ancienne et Moderne, vol. 48 (Paris : Michaud Éditeur, 1827), 523.

${ }^{16}$ In his introductory essay to the edition he published in 1868 of the letters of Marie Bellefonds, Alfred de Courtis tells us that one if her sisters was «Jeanne Françoise, alliée au marquis de Sébeville» [«Jeanne Françoise, married to the marquis de Sébeville»]. Here, he mixes up two of Marie's sisters: on the one hand, Jeanne de Bellefonds (1604-1656), marquise d' Amfreville, and Françoise de Bellefonds (1618-1703), marquise de Sébeville, on the other. See Alfred de Courtis. "Introduction," in Lettres de Madame de Villars a Madame de Coulanges (1679-1689), ed. Marie Gigault de Bellefonds, marquise de Villars (Paris : Plon, 1868), 7-8. [Hereafter Lettres].

${ }^{17}$ Louis de Rouvroy Saint-Simon, Memoires, t. I (Paris : Librairie Hachette, 1879), 77.

18 Antonio Castillo Gómez, Entre la pluma y la pared: una historia social de la escritura en los Siglos de Oro (Madrid: Akal, 2006), 21.

${ }^{19}$ José María Imízcoz Beunza y Lara Arroyo Ruiz, "Redes sociales y correspondencia epistolar. Del análisis cualitativo de las relaciones personales a la reconstrucción de redes egocentradas," Redes. Revista hispana para el análisis de redes sociales 21 (2011), https://revistes.uab.cat/redes/article/view/v21n2-imizcoz-arroyo (accessed 29th October 2019).

20 Paola Volpini. "Ambasciatori, cerimoniali e informazione politica: il sistema diplomatico e le sue fonti," in Nel Laboratorio della Storia, ed. María Pía Paoli (Roma: Carocci, 2013), 237-265. Pedro Cardim, "Nem Tudo se pode escrever. Correspondencia diplomática e información política en Portugal durante el siglo XVII," Cuadernos de Historia Moderna. Anejo IV (2005), https://revistas.ucm.es/index.php/CHMO/article/view/CHMO0505220095A (accessed 29th October 2019). Fernando Bouza. "Escribir en la corte. La cultura de la nobleza cortesana y las formas de comunicación en el Siglo de Oro," in Vivir el Siglo de Oro. Poder, cultura e historia en la época moderna. Estudios en homenaje al profesor Ángel Rodríguez. Sánchez. (Salamanca: Universidad de Salamanca, 2003), 77 100. 
Regarding female correspondence and its value for diplomatic history in the early modern age, James Daybell has no doubt in affirming that «female correspondents were central to maintaining political and kindship relations, contacts that could usefully be brought to bear on other occasions; and conveyance of news in letter was one of the chief ways in which these networks were strengthened». ${ }^{21}$ For the purposes of this research, the epistolary exchange that the marquise Marie de Bellefonds maintained with her friend Madame de Coulanges will allow us to show that the marquise was not foreign to political life at the court and that her actions had a projection that, until now, has been undervalued. The thirty-seven letters that the French ambassadress exchanged with Madame de Coulanges between 1679 and 1681 are a first-hand source to deepen our knowledge of female diplomacy at the court of Charles $\mathrm{II}^{22}$. Although we know that the French ambassadress in Madrid exchanged correspondence with Madame d'Uxelles, Madame La Fayette, Madame de Sévigné and other women of the court of Louis XIV, said documents have not been located ${ }^{23}$.

In April 1679, the marquis Pierre de Villars became the appointed representative of Louis XIV in Madrid, i.e. his ambassador at the court ${ }^{24}$. This was not the first time that the marquis had had a diplomatic mission in Madrid. In August 1668, after the Treaty of Aix-la-Chapelle or Aachen, he had been designed extraordinarily ambassador to announce the birth of Louis XIV's fifth child with Maria Theresa of Austria and to ensure. During his mission, the ambassador had to use his wits to gain favorable attitudes towards the French king, to against the Emperor, among the members of the Regency Council ${ }^{25}$. He would return for the second time to the troubled court of Madrid on $25^{\text {th }}$ November 1671 with the purpose of calming the regent Queen Mariana of Austria in relation to Louis XIV's

${ }^{21}$ James Daybell, "Gender, Politics and Diplomacy: Women, News and Intelligence Networks in Elizabethan England," in Diplomacy and Early Modern Culture, eds. Robyn Adams and Rosanna Cox (Basingstoke: Palgrave Macmillan, 2010), 103.

22 Unfortunately, only thirty-seven letters are known to have survived, but, judging by their content and cross-references, the epistolary corpus must have been larger. Madame de Villars' posthumous letters were published for the first time in Amsterdam and Paris in 1759, fifty-three years after her death. In 1760, they were published again in Amsterdam and in Germany for the first time. Two years after that, they are published once more in Paris and Amsterdam. During the nineteenthcentury, de Villars' posthumous letters appeared in three collective editions (1805, 1806 and 1823) with letters by Mmes. la Fayette, de Tencin, de Coulanges, de Ninon de Lenclos and Mademoiselle Aïssé. In this work we reference the nineteenth-century edition by Alfred de Courtois, which reproduces the original text from the first edition of 1759. I will maintain the original French text's writing, stress and punctuation and will include an English translation.

23 Marie de Rabutin-Chantal, marquise de Sévigné, Lettres de Madame de Sévigné da se famille et de ses amis, vol. 1 (Paris : Hachette, 1682-1867), 8.

24 "Liste chronologique des agents français en Espagne", en Inventaire Sommaire des Archives du département des affaires étrangères. Correspondance Politique, II, Espagne (Paris: Ministère des affaires étrangères, 1920).

${ }^{25}$ Louis XIV to the marquis de Villars, Saint-Germain, 16th August 1668. François Auguste Mignet, Négociations relatives à la succession d'Espagne sous Louis XIV, t. 3 (Paris : Imprimerie Royale, 1842), 384-388. 
intentions in the Netherlands and to assure, once again, the intentions of the Rex Christianissimus of respecting the Peace of Aix-la-Chapelle ${ }^{26}$. The intervention and power of the members of the Spanish nobility in matters of state during royal minority something that the French king was highly concerned about. In this regard, Villars' embassy had to keep the extended anti-French sentiment under control and earn sympathizers to their cause at the regent queen's court. In the case of death of the young monarch, having the support or opposition from the nobles was not a trivial issue. In the summer of 1672, French armies invaded the United Provinces, all the way to Utrecht, and, the following year, they laid siege to the city of Maastricht. This new attack of French imperialism provoked several reactions, such as the formation of the Grand Alliance of The Hague. King Louis XIV immediately attacked the Spanish Netherlands, the area of the Rhine, Catalonia and other territories that were part of the Spanish monarchy. In this context of war, ambassador Villars was expelled and had to return to Paris. As it has been previously mentioned, in April 1679, Villars returned for the third time to Madrid as extraordinary ambassador of the King of France in the context of the marriage of Charles II and Marie-Louise of Orleans, niece of Louis XIV. The Spanish and French monarchies had been main contenders in the Dutch War (1672-1678), and thus the marriage alliance agreed in Nijmegen (1678) involved the restoration of diplomatic relations between both courts. Although the Treaty of Nijmegen affected the territorial integrity of the Hispanic Monarchy, which had to cede the FrancheComté to the French, the marriage alliance with France implied the return of peace. In those days, spanish poets described Marie-Louise as the glory of France and the hope of Spain. With kindness and courtesy, the young French woman was received in court in the hope that she would become the mother of the heir to the crown. But three months before the princess of Orleans came to court and while Pierre de Villars was in Burgos finalizing the details of the Franco Hispanic marriage, Madame de Villars settled in Madrid with her children ${ }^{27}$.

After the royal wedding in Quintanapalla (Burgos), the monarchs entered Madrid on $2^{\text {nd }}$ December 1679. They arrived to Buen Retiro Palace and stayed there until the day of the queen's public entrance, on $13^{\text {th }}$ January $1680^{28}$. During this time, the royal couple had to stay secluded in Buen Retiro and were not allowed any

${ }^{26}$ Instructions from Louis XIV to the marquis de Villars, 21st October 1671. "Mémoire du roi pour servir d'Instruction au Sieur Marquis de Villars, s'en allant Ambassadeur extraordinaire en Espagne", Archives du Ministère des Affaires Étrangères [hereafter AAE], París, CP Espagne, 60, ff. 299-311. In Alfred Morel-Fatio \& Henry Léonardon, Recueil des Instructions données aux ambassadeurs et ministres de France depuis les traites de Westphalie jusqu'à la Révolution Française, Espagne, vol. I (Paris : Ancienne Librairie Germer Baillier et Félix Alcán éditeur, 1894), 260-273. Hereafter, Recueil.

27 «El propia día 19 (de agosto de 1679) llegó de Francia la Excelentísima Señora Marquesa de Villars, esposa del Excelentísimo Señor Marques, Embajador ordinario de S.M. Cristianisima». In La Gazeta ordinaria de Madrid, $\mathrm{n}^{\circ} 43,24 / 10 / 1679$, 273. Also on the arrival of Madame de Villars, see: Marie Catherine le Jumel de Berneville, countess d'Aulnoy, Relation du voyage d'Espagne (Paris: Desjonquères, 2005).

${ }^{28}$ María Teresa Zapata, La entrada en la Corte de Maria Luisa de Orleans. Arte y fiesta en el Madrid de Carlos II (Madrid: Fundación de Apoyo a la Historia del Arte Hispano, 2000). 
visitors. In a direct challenge against court etiquette, Madame de Villars requested an audience with the queen from her camarera mayor, or first lady of the bedchamber, the duchess of Terranova. This was initially denied. However, the marquise's petition reached the ears of both queens, Mariana of Austria and Marie-Louise of Orleans, who begged the king to exceptionally allow the French ambassadress to visit Buen Retiro. According to the duke of Maura, the widowed queen's intervention was decisive. Doña Mariana «remembering how much relief the frequent visits from the German ambassadors had meant for her when she had just arrived from Vienna, she garners and gets a similar treatment from her son to her female successor». ${ }^{29}$. Then, the Gazeta published:

On Sunday 10th of the present month [December 1679], the Excellent Lady Marquise de Villars, Ambassadress of France, for the first time, after the arrival of the Queen Our Lady, went to announce her the events that may bring the utmost prosperities of her state ${ }^{30}$.

Although Marie-Louise was incognito in Buen Retiro and she could only receive visitors from the royal family, the King and Queen Mother authorized the visit of the French ambassador's wife the afternoon of $14^{\text {th }}$ December $1679^{31}$. That afternoon, the young monarch sat on a couch and the queens lied on the cushions, as stated by protocol. During the audience, a Flemish dwarf called Luisillo served as interpreter between the French ambassadress and the King. One of the gentlewomen showed the Madame her guardainfante ${ }^{32}$. Immediately, the French ambassadress responded that she had trouble believing that the artifact had been created to be used by human beings. The King agreed and all those present made welcoming gestures to the visitor. They shared a meal prepared by French cooks straight after that, and after the King left, the queens did their own. In the memoirs attributed to the marquis de Villars we are told that, in private, the young queen approached the ambassadress and confided in her how bored and tormented she felt at the court ${ }^{33}$. Maura, based

\footnotetext{
${ }^{29}$ «recordando de cuánto alivio moral le fueron, recién venida de Viena, las frecuentes visitas de los Embajadores alemanes, recaba y obtiene de su hijo trato análogo para su sucesora». Gabriel de Maura, Vida y reinado de Carlos II, t. I (Madrid: Espasa-Calpe, 1954), 346.

30 «El domingo 10 del corriente (diciembre de 1679), fue la Excelentísima Señora Marquesa de Villars, Embajadora de Francia, primera vez, después del arribo de la Reina Nuestra Señora a anunciarle los sucesos que conduzcan a las mayores prosperidades de su estado». In La Gazeta ordinaria de Madrid, $\mathrm{n}^{\circ} 51,19 / 12 / 1679,353$. According to Alfred de Courtis, La Gazeta mistakes the date of the first visit, which was not on the 10th but on the 14th of December. See Alfred de Courtis. "Notes de Lettres" in Lettres, 222. In fact, the letter dated 15/12/1679 confirms that the first visit was on 14th December.

31 «Je fus hier au Retiro, cette maison où le roi et la reine sont présentement». Madame de Villars to Madame de Coulanges, 15th December 1679. In Lettres, p. 90.

32 The guardainfante was a large farthingale, similar to a crinoline, which hollowed women's skirts. Under this artifact they would put on their petticoats and, over that, the skirt and basquina.

${ }_{33}$ Pierre de Villars, Mémoires de la cour d'Espagne, de 1679 à 1681 (Paris : Plon, 1893), 105. On the origin and function of said memoirs, see Gabriel de Maura, María Luisa de Orleans, reina de España. Leyenda e historia (Madrid: Saturnino Calleja, c. 1940), 56-57.
} 
on the memoirs of the French ambassador, reproduced that image of a sad princess, who is beleaguered by «the company of half a hundred of women, whose incessant chatter she cannot follow»..$^{34}$

The news of the audience between the French ambassadress and the monarchs reached Versailles. On 30th January 1680, Louis XIV wrote to the marquis de Villars:

since the Marquise de Villars has been granted permission to see the young queen and can be informed of everything the queen says and does, as well as of the treatment she receives, I wish to be informed of everything in detail, without disguising anything 35 .

As it has been previously mentioned, diplomatic couples in the Baroque era used different strategies of marital collaboration with the purpose of guaranteeing their mission. According to Ana Álvarez López, the ambassadors had three functions: to gather information, to negotiate, and to represent their monarch ${ }^{36}$. The need to garner information from an "other" was one of the driving forces of the evolution of diplomacy ${ }^{37}$. For this purpose, Pierre de Villars was used to carrying a diary where he wrote down every detail of what he saw, heard, learned or found out ${ }^{38}$. The ambassador had the obligation of sending any information that he considered relevant to the French court and, when possible, he had to attach the evidence to prove said information: briefs, copies of documents from the hosting court, pamphlets, satires, prints, books, etc. ${ }^{39}$. When there was no material proof, the ambassador named the person who had served as source. In this regard, Villars stressed that his wife was one of his main agents at the court, which was possible due to her friendship with the queen: «Madame de Villars has the honour of seeing the queen often, through your order, and because this is seen with good eyes from the Palace» ${ }^{40}$.

It is important to underscore that the French ambassadress had ample freedom of movement and most of the time visited the Palace without her husband. Far from seeing this as a problem, the ambassadress' independence aided in the

\footnotetext{
34 «la compañía de medio centenar de mujeres, cuya charla incesante no acierta a seguir». Maura. Vida y reinado, 347.

35 «comme la marquise de Villars a permission de voir la jeune reine et qu'elle peut être informée de tout ce qu'elle dit et de tout ce qu'elle fait, comme aussi du traitement qu'elle reçoit, je désidere que vous me fassiez savoir toutes choses en détail, sans y rien déguiser». Louis XIV to the marquis de Villars, 30th January 1680. In Villars, Mémoires de la cour, 60-61.

36 Ana Álvarez López, La fabricación de un imaginario (Madrid: Cátedra, 2008), 94.

${ }^{37}$ Ibídem, 145.

38 Maura, María Luisa de Orleans, 56.

${ }^{39}$ François de Callières, Negociando con príncipes. Reglas de la diplomacia y Arte de la negociación (Madrid: La Esfera de los Libros, 2001), 157-158.

40 «Madame de Villars a l'honneur de voir souvent la reine, par son ordre et parce qu'on le trouve bon au palais». Marquis de Villars to Louis XIV, 16th May 1680. Quoted in Courtis, "Introduction", 57.
} 
attainment of the embassy's objective. The Rex Christianissimus emphasized the importance, among his representatives in Madrid, of those who had shown some ability in re-establishing bonds in court society through family connections in favour of the gathering of information. As the aforementioned letter from King Louis XIV sent the marquis on $30^{\text {th }}$ January1680 shows, the French monarch was very aware that one of his main agents and collaborators in Spain was the cunning marquise. However, the French ambassadress was not only a direct source of information, but also an intermediary. Because of his wife's social and political skills, ambassador de Villars came into contact with a group of monks and ladies who, after having established a personal relationship of trust with him, unconsciously began to let him know valuable information ${ }^{41}$. The French ambassadress worked actively so that her husband was accepted in court society knowing that this would grant him access to a greater level of information and give him the capacity to influence many people. In this regard, the talents of his wife allowed the ambassador to earn the love of King Louis and move up in his diplomatic career. As the mission ended, the de Villars were received in Paris with accolades and honours. On $7^{\text {th }}$ May 1683, Pierre was named Conseiller d'État d'épée - title that only three knights held in France- and, on $31^{\text {st }}$ December 1688, the king named him Knight of the Order of the Holy Spirit.

During their stay in Madrid, the de Villars did not only use their time for political matters, but also focused on economics. France's interest on the state of Spanish economy increased in times of Colbert, who showed interest in augmenting the influx of precious metals and avoiding their leaving the country ${ }^{42}$. The marquis had the obligation of negotiating a series of amendments by Colbert himself to ensure relevant benefits for French commerce ${ }^{43}$. This explains the marquise's interest for the state of Spanish economy. On $26^{\text {th }}$ January 1680, the marquise wrote to her interlocutor in France: «Spain does not seem an opulent country to me» ${ }^{44}$. The letter was written after the promulgation of a series of economic laws that sought to halt the constant devaluing of the currency and which unsuccessfully provoked market shortages ${ }^{45}$. Seven months later, she insisted that in the Spanish monarchy «misery increases every day, and the value of the currency does not improve» ${ }^{46}$. Similar

\footnotetext{
41 Villars used to say that one only needed to let monks and ladies speak. Marquis de Villars to Louis XIV, 1 de mayo de 1669. AAE, París CP Espagne, 59, f. 323.

${ }^{42}$ Pierre Goubert, Le siècle de Louis XIV (Paris : Editions de Fallois, 1996).

43 "Memoire pour servir d'instruction au sieur marquis de Villars...". In Recueil, 287

44 «L'Espagne ne me parait pas opulente». Madame de Villars to Madame de Coulanges, 26th January 1680. In Lettres, 105.

45 In this context of economic weakness, Charles II sent Medinaceli the following note: «I have acknowledge that the formality of the Government of my Monarchy and current events are in need of a Prime Minister; and, requiring your presence, I have no doubted in commissioning you to help me thus. I the King». [«He reconocido que la formalidad del Gobierno de mi Monarquía y las ocurrencias de ahora necesitan de Primer Ministro; y habiendo de tenerle, no he dudado encargarte me ayudes en esta forma. Yo el Rey»]. Quoted in Maura, Vida y reinado, 352. See also Henry Kamen, La España de Carlos II (Madrid: Crítica, 1981), 169-172.

46 «la misere augmente ici tous le jours, et les monnoies n'y sont point rehaussées». Madame de Villars to Madame de Coulanges, 29th August 1680. In Lettres, 140.
} 
assertions are reiterated in her letter from $26^{\text {th }}$ September, in which she is horrified by the rise of poverty in Madrid ${ }^{47}$. On $6^{\text {th }}$ February 1681, she writes that misery is also found within the Royal Alcázar of Madrid and that the queen's chambermaids do not receive their food as appropriate ${ }^{48}$. The impressions of the French ambassadors on Spanish economy underscore its irreversible decay, which has been disproved by historiography in the second half of twentieth century ${ }^{49}$. There are several references regarding the monarchy's lack of money and their kingdom's poverty. On $27^{\text {th }}$ June 1681, the ambassador stated that, despite the good harvest, misery was still abundant ${ }^{50}$. In the ambassadress' epistles, we continuously find terms such as estat penchat (decline), foiblesse (weakness), pauvreté (poverty), desordre (disorder), and misère (misery) to describe the state of the monarchy in Spain.

The French ambassadress used tools and strategies to earn the queen's affection and friendship -a goal she achieved successfully and without too much difficulty. The first advantage she had was that both Maries spoke the same language. The sovereign had taken Spanish lessons with an Irish teacher. However, during the first months of her reign she had not managed to master Cervantes' language and, therefore, she greatly appreciated the conversation in French she was able to maintain with the marquise: «The queen finds joy in seeing a Frenchwoman and speaking in her natural tongue. We sing opera arias together. Sometimes I sing a minuet that she dances» ${ }^{51}$. "We sing like cicadas. She reads operas; she plays the harpsichord wonderfully, the guitar relatively well; she learnt to play the harp in no time» ${ }^{52}$.

The ambassadress, an actress in Baroque politics, managed to master the art of conversation and earn the love of the Queen. In general, Marie used to speak about the subjects that Marie-Louise was interested in to gain the queen's sympathies. According to what the letters inform, Marie-Louise's favourite topics included music,

${ }^{47}$ Madame de Villars to Madame de Coulanges, 26th September 1680. In Lettres, 145-147.

48 «I do not wish to speak more to you about the misery of this kingdom. Hunger has reached the Palace. Yesterday I was with eight or ten chambermaids and Molina, who said they have not received their bread and viands in a long time». Original text : «Je ne vous parlé pas de la misère de ce royaume. La faim est jusques dans le palais. J'étois hier avec huit ou dieux camaristas et la Molina, qui disoient qu'il y avoit fort longtems qu'on ne leur donnoit plus ni pain ni viande». Madame de Villars to Madame de Coulanges, 6th February 1681. In Lettres, 164.

${ }^{49}$ In no spirit of exhaustiveness, we recommend Bartolomé Yun Casalilla, "Del centro a la periferia: la economía española bajo Carlos II," Studia Histórica. Historia Moderna 20 (1999), http://revistas.usal.es/index.php/Studia_Historica/article/view/4818 (accesed 5th November 2019). Antonio Domínguez Ortiz, "La crisis de Castilla en 1677-1687," in Crisis y decadencia en la España de los Austrias (Barcelona: Ariel, 1969), 195-217. Henry Kamen. "The decline of Spain: a historical myth?" Past \& Present, 81 (1978): 24-50.

${ }^{50}$ Marquis de Villars to Louis XIV, 27th June 1681. AAE, Paris CP Espagne, 66, ff. 128-129.

51 «La reine a du plaisir à voir une Françoise et parler sa langue naturelle. Nous chantons ensemble des airs d'opera. Je chante quelquefois un menuet qu'elle danse». Madame de Villars to Madame de Coulanges, 28th May 1680. In Lettres, 128.

52 «Nous chantons comme des cigales. Elle lit des opéras; elle joue à merveille de clavessin, assez bien de la guitare ; en moins de rien elle a appris à jouer de la harpe». Madame de Villars to Madame de Coulanges, 13th June 1680. In Lettres, 131. 
dance, drawing, horse riding, small game hunting, theatre and fashion. In addition to the long conversation sessions, the Queen and the ambassadress did several activities together: they read operas, played musical instruments, sung and danced minuets and passepied $^{53}$. In spite of the great number of leisure activities they shared, the afternoons at the Alcázar must have also been tedious, as Marie tells in her letters that boredom was so dense that it could be smelled, seen and touched. In those circumstances, the ambassadress' words «quickly adapted to the only tone that sounded well to royal ears, that of considering and commiserating [the queen] as innocent victim, sacrificed in a barbaric way for the sake of stately affairs». The excessive praise that Marie used to refer to the queen caused her to have the fame of obsequious, an easy vice to fall into in court society ${ }^{54}$. In the queen's chamber, Gabriel de Maura underscores, some women specialized in praising their lady's defects and, among them, the French ambassadress was one of the most obliging ${ }^{55}$.

\section{3. «THE DANGEROUS FRIENDSHIP BETWEEN THE QUEEN AND THE MARQUISE». DESTITUTION OF THE DE VILLARS AND THE RETURN TO PARIS}

In the summer of 1680, Marie had managed to become Queen Marie-Louise of Orleans' closest confidant. This was celebrated in Versailles, where the fruits of her labours were acknowledged together with those of the French ambassadors' in Madrid. Although the Peace of Nijmegen and the marriage alliance had determined the end of the war and the restoration of diplomatic relations between French and Spain, the presence of the ambassador Villars and his wife in Madrid and their ability in influencing the queen generated an atmosphere of distrust, misgivings and antipathies in the spanish court. The years of the embassy of Villars (1679-1681) were a period of peace. The declaration of war from Spain to France would come on October 26th, 1683 after the French occupation of Strasbourg and Luxembourg ${ }^{56}$. However, tension and mutual distrust were a coomon place before the War of the Reunions (1683-1684). For this reason, the friendship between the queen and the ambassadress caused suspicion.

The different parties at the court, from Prime Minister Medinaceli to the entourage of the Queen Mother, who exerted her influence again over her weak son, believed or pretended to believe that Villars manipulated the young queen's wishes and directed her conduct against them. His wife was accused of taking advantage of her

53 Madame de Villars to Madame de Coulanges, 8th August 1680. In Lettres, 136.

${ }^{54}$ During the seventeenth century, European courts were filled with people who tried to prosper at any cost. The flatterer built a career in these environments.

${ }_{55}$ Maura, María Luisa de Orleans, 126.

${ }^{56}$ John Lynn, The Wars of Louis XIV, 1667-1714 (Harlow-Essex: Longman, 1999), 163-168. 
position as ambassadress and of the friendship offered to her by Marie-Louise to arouse intrigue inside the palace ${ }^{57}$.

The Prime Minister, Duke of Medinaceli, was the main adversary of the French ambassadors -an issue about which the ambassadress $\mathrm{knew}^{58}$. Medinaceli accused ambassador de Villars for his inadmissible influence in the Spanish monarchy's internal affairs, using the close friendship between him and his wife with the queen as evidence. José Manuel de Bernardo Ares holds that Medinaceli's antiFrench foreign policy was translated into concrete measures, among which the separation of the French ambassadress from the queen's intimate circle stands out, as well as the eventual destitution of Villars from the French embassy. These measures were followed by the sanction against the Duke of Osuna, caballerizo mayor or Great Equerry of the Queen in 1683, the alienation of queen's nurse Nicole Duperroy, known as "la Cantina", in 1685, and the Queen's death by poisoning in $1689^{59}$. María Victoria López-Cordón Cortezo has said that the queen's freedom of movement in political action was always very limited «given that she was always under the strict control of the duke of Medinaceli until his demise in 1685, and later under the count of Oropesa, who feared her possible influence over the King ${ }^{60}$. But Medinaceli and Oropesa were not the only ones that looked upon Marie-Louise's French surroundings with distrust.

The Italian ambassadors observed the power the French ambassadors had over the young queen and judged it as pernicious. On $12^{\text {th }}$ September 1680, the ambassador of the sixth grand duke of Tuscany accused the de Villars of excessive meddling in matters of the Queen's royal chamber. After the destitution of the duchess of Terranova from her role as camarera mayor, Marie and her husband persuaded Marie-Louise to name Catalina de Mendoza y Sandoval, duchess of the Infantado and public enemy of Medinaceli, as her successor. The project failed and, at the behest of the queen mother and the prime minister, doña Juana de Armendáriz y Ribera, widowed duchess of Alburquerque, was named as the duchess of Terranova's successor. Cosimo III of Medici's envoy describes Madame de Villars in the following terms:

\footnotetext{
${ }^{57}$ «Les divers partis de la cour, depuis le premier ministre Medinaceli jusqu'à l'entourage de la reine mère, dont l'influence s'exerçait à nouveau sur son faible fils, croyaient ou feignaient de croire que Villars disposait des volontés de la jeune reine et dirigeait sa conduite à leur détriment. On accusait sa femme de profiter de sa situation d'ambassadrice et de l'amitié que lui témoignait Marie-Louise pour intriguer au palais». Alfred Morel Fatio. "Le marquis de Villars, 1679-1681," in Recueil, 278.

58 «le premier ministre a fait négocier notre retour a France» [«the prime minister has negotiated our return to France»]. Madame de Villars to Madame de Coulganges, 3rd April 1681. In Lettres, 168.

${ }^{59}$ José Manuel de Bernardo Ares, Luis XIV, rey de España. De los imperios plurinacionales a los estados unitarios (1665-1714) (Madrid: Iustel, 2008), 126-130.

60 «ya que estuvo sometida al estricto control del duque de Medinaceli hasta su caída en 1685, y después del conde de Oropesa, que temieron su influencia sobre el rey». María Victoria López-Cordón Cortezo, "Las mujeres en la vida de Carlos II," en Carlos II. El rey y su entorno cortesano, ed. Luis Ribot (Madrid: CEEH, 2009), 125.
} 
lady of great curiosity and skill, who has been able to find her way into the domestic affairs of this Royal Palace and Court, and though she lost the battle concerning the duchess of the Infantado, who they tried to introduce into the palace as chief ladyin-waiting, she still continues with her plot ${ }^{61}$.

A month later, Abbot Ridolfi warns his lord again that «the penetration of this lady into the Palace continues, intrusively encouraging the Queen and poisoning as well all of Her Majesty's ladies ${ }^{62}$. On his part, Venetian ambassador Federico Cornaro suggested that the French ambassador and his wife sought to strengthen the queen's authority to establish the French project against Medinacelii. ${ }^{63}$. His successor in the Venetian embassy, Giovanni Cornaro, read his report at the Senate on $28^{\text {th }}$ July 1683. At this time, he highlighted that the reigning queen «still has a highly ingrained inclination towards the court in which she was born» and that, in Madrid, her closeknit French circle was viewed with mistrust ${ }^{64}$. In every case, the Italian embassies agree that the destitution of the de Villars from the French embassy was both necessary and urgent in order to reinstate calm at the court.

Aware of the fact that the growing familiarity with the Queen had sparked a series of ill-natured rumours, the French ambassadress took discretional measures. On the one hand, she began to visit Marie-Louise at times in which the King and Medinaceli were not at the Alcázar. For example, on $1^{\text {st }}$ May 1680, seizing the chance that Charles and his minister were in El Escorial, the marquise writes: «I returned to the Palace ${ }^{65}$. On the other hand, the marquise mentions in her letters that she used to talk to the queen through a window that communicated the palace with the gardens of the Royal Monastery of the Incarnation: «Now the queen and I see each other as much as we want through a window that looks on a great garden of a nunnery called Incarnation and which is joined to the Palace» ${ }^{66}$.

The clever duchess of Terranova had noticed quite early that the Queen and her maids were prone to establishing this type of contact by looking out from windows. In fact, the women of the court «have learned in Spain the language of

${ }^{61}$ Letter from Abbot Carlo Ridolfi to Secretary Juan Amoni, 12th September 1680. Archivio di Stato, Florence, filza 5065. Quoted in María Luisa Lobato. "Miradas de mujer. María Luisa de Orleans, esposa de Carlos II, vista por la marquesa de Villars (1679-1689)," en Teatro y poder en la época de Carlos II. Fiestas en torno a reyes y virreyes, ed. Judith Farré Vidal (Madrid-Frankfurt am Main-México: Iberoamericana-Vervuert-Universidad de Navarra, 2007), 18.

${ }^{62}$ Letter from Abbot Carlo Ridolfi to Secretary Juan Amoni, 24th October 1680. Archivio di Stato, Florence, filza 5065. Ibídem, 18.

${ }^{63}$ Federico Cornaro. "Relazione di Spagna di Federico Cornaro, Ambasciatore a Carlos II, 16791681," in Relazioni degli Stati Europei lette al Senato degli Ambasciatori Veneti nel secolo decimosettimo. Spagna, ed. Nicolo Barozzi e Guglielmo Berchet, vol. II (Venecia: Pietro Naratovich, 1860), 437-468. Maura, Vida y reinado, 120-121.

${ }^{64}$ Giovanni Cornaro. "Relazione di Spagna di Giovanni Cornaro, Ambasciatore a Carlos II, 16811682," in Ibidem, 481.

65 «e reviens du palais». Madame de Villars to Madame de Coulanges, 1st May 1680. In Lettres, 125.

66 «Nous regardons présentement la reine et moi, tant que nous voulons, par une fenêtre qui n'a de vue que sur un grand jardin d'un couvent de religieuses qu'on appelle l'Incarnation, et qui est attaché au palais». Madame de Villars to Madame de Coulanges, 12th september1680. In Lettres, 144. 
fingers, which they use to communicate with the street from higher floors, and they also, on some occasions, elaborate on what is discussed out loud, through the fences of the mezzanine» ${ }^{67}$. In several cases, Marie-Louise was scolded for this type of indiscretions, which, although understandable for someone who had not yet reached the age of twenty, were considered undignified for a person of her quality and condition.

What did their detractors criticize of the de Villars? Was the French ambassadress truly a dangerous figure with power for action at the court? Madame de Villars was mainly criticized on two matters. First, some were aggravated by the fact that the French ambassadress did not fully comply with palace etiquette and, therefore, was a bad influence to Marie-Louise. In Spain, ceremony was understood as a set of rules of ritualized conduct that regulated public as well as private life ${ }^{68}$. Hence, it held an enormous symbolic value and a relevant political load. The queen's first lady of bedchamber, the duchess of Terranova, opposed to the frequent visits of the ambassadress to her lady and, many times, she interrupted them while they talked or sang in order to remind Marie-Louise of her obligations ${ }^{69}$. Madame de Villars did not think the camarera mayor had personal feelings of hatred towards her and understood the rejection to her presence at court as exclusively related to her French origin: «Madame de Terranova feels a great aversion against France and all things French ${ }^{70}$. Likewise, the maids must have not seen with kind eyes the failed project of naming one of the daughters of the de Villars as one of the Queen's attendants. In the epistles, Madame de Villars suggests it was her who rejected such an honor because her daughter was still too young, the wages were too low and because the queen was surrounded by the most dignified ladies that could exist ${ }^{71}$. However, we know that the decision was more associated to Medinaceli's anti-French policy than a personal decision by the marquise. Criticism like this mostly occurred within the royal chamber and affected the female circle of the queen. All in all, we believe these were minor accusations that may have been tolerated, given that the conflicts generated by matters of etiquette or issues regarding appointments were frequent at the time.

Notwithstanding, there were other reproaches that were more serious and, therefore, called for an inquiry and concrete action. At the court, many people

\footnotetext{
${ }^{67}$ «han aprendido en España el lenguaje de los dedos, usan de él para dialogar con la calle desde los pisos altos, y aprovechan también algunas raras ocasiones para puntualizar de viva voz lo dialogado, a través de las rejas del entresuelo». Maura, Vida y reinado, 379.

68 María Albaladejo Martínez, "Fasto y etiqueta en la Casa de Austria," Imafronte 19-20 (2008), https://revistas.um.es/imafronte/article/view/200791 (accessed 12th November 2019). Félix Labrador Arroyo, "La formación de las Etiquetas Generales de Palacio en tiempos de Felipe IV: la Junta de Etiquetas, reformas y cambio en la Casa Real," en La Casa de Borgoña: la Casa del rey de España, ed. Félix Labrador Arroyo y José Eloy Hortal Muñoz (Leuven: Leuven University Press, 2014), 99-128.

${ }^{69}$ We recommend the thought-provoking work by María del Carmen Simón Palmer about "El silencio en la Casa de la Reina," Lectora 13 (2007): 45-59.

70 «Madame de Terranova ait une grande aversion por la France et pour le François». Madame de Villars to Madame de Coulanges, 5th September 1680. In Lettres, 141.

${ }^{71}$ Ibidem, 142 y 151-152.
} 
explicitly said that the marquise was an agent from the French embassy working together with her husband for Louis XIV's interests in Spain. Marie de Villars was seen as intermediary between the ambassador and the queen to gather confidential information and, at the same time, instruct the queen on a series of steps that she had to follow ${ }^{72}$. If we observe the instructions given to ambassadors and the epistolary documents, this interpretation does not seem completely unreasonable. On $27^{\text {th }}$ July 1679, the marquis de Villars writes to the Foreign Affairs secretary Simon Arnauld de Pomponne that, even though don Juan José of Austria had organized Marie-Louise's Royal Household with his own appointments, if the Queen acted carefully, she would manage to have a great influence over her husband, which would be beneficial for France ${ }^{73}$. On 3rd September 1679, the marquis of Pomponne replies by asking Villars to take care of Marie-Louise and warns him that it would soon be decided what would be done with her ${ }^{74}$. During the entire decade of 1680, the French embassy sought to make of queen Marie-Louise a political tool in the service of her uncle. It was expected of her to influence her husband so that certain individuals were appointed to key positions in the monarchy's Councils. The instructions from Louis XIV to Villars' successor, marquis de Feuquiéres, leave no room for doubt.

[The marquis de Feuquiéres] must not forget this princess [...] in order to do everything which will depend on her to make the Catholic King entrust the position of minister only to someone whose counsel is more peaceable and, if possible, who has less skills for government than the duke of Medinaceli ${ }^{75}$.

If King Charles II of Spain were to die, the queen had to immediately declare her support for the French candidate and bring forth great part of the nobility. French ambassador Rébenac had precise instructions for Marie-Louise: he had to remind her of her duty to France by reason of her birth, the love she had for her uncle and how beneficial it would be for her if the heir were the dauphin. The queen was warned by then: if she did not support the dauphin for the succession, Louis

\footnotetext{
72 Lucien Bély, "Espions et ambassadeurs à l'époque moderne," en Ambassadeurs, apprentis espions et maîtres comploteurs. Les systèmes de renseignement en Espagne à l'époque moderne, ed. Béatrice Pérez (Paris: PUPS, 2010), 21-30.

${ }^{73}$ Villars to Pomponne, 27th July 1679. AAE, Paris CP Espagne, 64, f. 75. On the marquis de Pomponne, see Louis Delavaud. Le marquis de Pomponne, ambassadeur et secrétaire d'état, 1618-1699 (Paris : Plon, 1911).

74 Pomponne to Villars, 3rd September 1679. AAE, Paris CP Espagne, 64, f. 97.

75 «[Feuquiéres] il ne doit rien admettre pour oublier cette princesse (...) à faire tout ce qui dépendra d'elle pour porter le Roi Catholique à ne confier la poste de ministre qu'à quelqu'un de son conseil qui soit plus pacifique et, s'il se peut, qui ait encore moins de talens pour gouverner que le duc de Medinaceli». Instructions from Louis XIV to marquis de Feuquiéres, 16th February 1685 "Mémoire pour servir d'instruction au sieur marquis de Feuquiéres Conseiller ordinaire du Roi en son Conseil d'Estat, lieutenant general des armes de Sa Majesté... en qualité d'ambassadeur Extraordinaire de Sa Majesté”. AAE París, CP Espagne, 71, f 12-35. In Recueil, 351.
} 
XIV would remove the protection she enjoyed from him $^{76}$. As José Manuel de Bernardo Ares has stressed, Marie-Louise was the chosen tool by Louis XIV during the decade of 1680 to develop his plan regarding the Spanish monarchy ${ }^{77}$. Thus, Marie Gigault de Bellefonds worked as a link between the Catholic Queen, ambassador Villars and the French King. The decoding of this axis of relationships and intentions aroused the animosity with the different groups at the court, among which their main enemy was the duke of Medinaceli. Moreover, a close reading of the ambassadress' letters shows us that Marie was not just a bridge between MarieLouise and her uncle, but also with great part of the French nobility: «I will tell the Queen today all that you write to me of honour and kindness for her» ${ }^{78}$; «I am waiting for the Queen's return from Escorial to show her everything you tell me about her in your letter» ${ }^{79}$.

There is no doubt that Queen Marie-Louise was involved in political life at court and that she had a close relationship with the agents of the French monarchy in Madrid. In the first years, the Queen's closeness with the marquise de Villars was mainly due to socio-cultural reasons but were also loaded with political significance. It would be the understanding of the political meaning of this friendly bond which would determine the destitution of ambassador de Villars and his return to Paris ${ }^{80}$.

In 1681, the friendship between the Queen and the French ambassadress had become a matter of state. Aware of this, and perhaps suspecting that her correspondence was being read, Marie begins to separate herself from stately affairs in her last letters. On 3rd April 1681, she wrote: «the king and queen are greatly united [...] I do not know if the king tells her State secrets; we never speak of such subjects with the queen ${ }^{81}$. Her last letters give the impression of having been written more for her enemies' eyes than those of Madame de Coulanges. The French ambassadress strongly stresses that she had a clear conscience and that she always stayed away from rumours. However, the influence the prime minister had over Charles was greater than any pleas made by Queen Marie-Louise. The King of Spain formally protested to his cousin and brother-in-law King Louis XIV of France asking

\footnotetext{
76 "Mémoire trè secret pour servir d'instruction au sieur comte de Rebenac, Ambassadeur Extraordinaire Du Roi en Espagne”. AAE, Paris CP Espagne, 74, ff. 165-209. In Recueil, 393.

77 José Manuel de Bernardo Ares, "El papel estelar de las reinas en la diplomacia francesa: María Luisa de Orleáns (1679-1689) y María Luisa Gabriela de Saboya (1701-1714)," en Tiempo de cambios: guerra, diplomacia y política internacional de la Monarquía Hispánica (1648-1700), ed. Porfirio Sanz Camañes (Madrid: Actas, 2012), 265-268. Id. Luis XIV, rey de España..., pp. 125-130.

78 «Je dirai aujourd'hui à la reine tout ce que vous m'écrivez d'honéte et d'obligeant pour elle». Madame de Villars to Madame de Coulanges, 26th September 1680. In Lettres, 145.

${ }_{79}$ «'attends la reine à son retour de l'Escorial, pour lui faire voir tout ce que vous me dites d'elle dans votre lettre». Madame de Villars to Madame de Coulanges, 31st October 1680. In Lettres, 151.

${ }^{80} \mathrm{On}$ the political sense of friendship within French nobility in the modern age: Jean Marie Constant. "L'amitié : le moteur de la mobilisation politique dans la noblesse de la première moitié du XVIIe siècle," in La Noblesse en liberté XVIe-XVIIIe siècles (Rennes : Presses Universitaires de Rennes, 2004), 173-187.

81 «le roi et la reine sont dans une grande union. [...] Je ne sais pas si le roi lui communique les secrets de l'Etat; c'est ce qui n'est jamais entré dans les conversations que j'ai l'honneur d'avoir avec elle». Madame de Villars to Madame de Coulanges, 3rd April 1681. In Lettres, 168.
} 
for the removal and substitution of de Villars from the embassy. In January 1682, count de la Vauguyon became the new French ambassador in Madrid.

\section{CONCLUSIONS}

The role the marquise Marie Gigault de Bellefonds performed at the court of Charles II of Spain perfectly illustrated the active participation that ambassadresses had in international politics during the seventeenth century. In this article, we have shown that the de Villars worked as a team for the fulfilment of the French embassy's political goals. Likewise, we have evidenced that the marital relationship cannot be simply considered one of dependence of Marie to her husband. The French ambassadress had significant free rein of action at the court and worked collaboratively with her husband. Marie's social skills allowed her to earn the love of Queen Marie-Louise, gain privileged access to certain spaces of power, gather information for the French agency and build new social networks. However, the reading of the political meaning of the French marquise at the Spanish court aroused the animosity of the different groups at the court, among whom we can identify the duke of Medinaceli, Charles II's prime minister, as the de Villars' main adversary. At the Catholic King's court, everyone agreed that Madame de Villars was an intermediary between the King of France, the French embassy and the Queen of Spain. Thus, it was deemed that the conflict would be resolved by the physical separation of the marquise. In January 1682, the de Villars left Madrid and, a few months later, they were received in a public ceremony with honours at the court in Versailles. 


\section{BIBLIOGRAPHY}

Aggestam, Karine and Towns, Ann, "The gender turn in diplomacy: a new research agenda," International Feminist Journal of Politics 21 (2019): 9-28. https://doi.org/10.1080/14616742.2018.1483206

Aikin, Judith, A Ruler's Consort in Early Modern Germany: Aemilia Juliana of SchwarzburgRudolstadt (Farnham: Ashgate, 2014).

Albaladejo Martínez, María, "Fasto y etiqueta en la Casa de Austria," Imafronte 19-20 (2008): 9-19.

Álvarez López, Ana, "Los negocios de Luis XIV en Madrid," Revista de Historia Moderna 25 (2007): 179-206. https://doi.org/10.14198/RHM2007.25.07

.- La fabricación de un imaginario (Madrid: Cátedra, 2008).

Bastian, Corine et al., Das Gescblecht der Diplomatie. Geschlechterrollen in den Außenbeziehungen vom Spätmittelalter bis zum 20. Jahrbundert (Köln: Böhlau, 2014).

Bély, Lucien. "Espions et ambassadeurs à l'époque moderne," en Ambassadeurs, apprentis espions et maîtres comploteurs. Les systèmes de renseignement en Espagne à l'époque moderne, ed. Béatrice Pérez (Paris: PUPS, 2010).

Bernardo Ares, José Manuel de. "El papel estelar de las reinas en la diplomacia francesa: María Luisa de Orleáns (1679-1689) y María Luisa Gabriela de Saboya (1701-1714)," en Tiempo de cambios: guerra, diplomacia y política internacional de la Monarquia Hispánica (1648-1700), ed. Porfirio Sáenz Camañes (Madrid: Actas, 2012), 265-268.

- Luis XIV, rey de España. De los imperios plurinacionales a los estados unitarios (1665-1714) (Madrid: Iustel, 2008).

Bouza, Fernando. "Escribir en la corte. La cultura de la nobleza cortesana y las formas de comunicación en el Siglo de Oro," en Vivir el Siglo de Oro. Poder, cultura e historia en la época moderna. Estudios en homenaje al profesor Ángel Rodríguez. Sánchez (Salamanca: Universidad de Salamanca, 2003), 77-100.

Callières, François de, Negociando con príncipes. Reglas de la diplomacia y Arte de la negociación (Madrid: La Esfera de los Libros, 2001). 
Campbell Orr, C., Queenship in Europe, 1660-1815: The Role of the Consort, Cambridge, Cambridge University Press, 2004.

Cardim, Pedro, "Nem Tudo se pode escrever. Correspondencia diplomática e información política en Portugal durante el siglo XVII," Cuadernos de Historia Moderna. Anejo IV (2005): 95-128.

Cassidy, Jennifer, ed., Gender and Diplomacy (London and New York: Routledge, 2018).

Castillo Gómez, Antonio, Entre la pluma y la pared: una historia social de la escritura en los Siglos de Oro (Madrid: Akal, 2006).

Constant, Jean Marie. "L'amitié : le moteur de la mobilisation politique dans la noblesse de la première moitié du XVIIe siècle," La Noblesse en liberté (XVIeXVIIIe siècles (Rennes: Presses Universitaires de Rennes, 2004). https://doi.org/10.4000/books.pur.18086.

Cornaro, Federico, "Relazione di Spagna di Federico Cornaro, Ambasciatore a Carlos II, 1679-1681," Relazioni degli Stati Europei lette al Senato degli Ambasciatori Veneti nel secolo decimosettimo. Spagna, eds. Nicolo Barozzi e Guglielmo Berchet, vol. II (Venecia: Pietro Naratovich, 1860).

Cornaro, Giovanni, "Relazione di Spagna di Giovanni Cornaro, Ambasciatore a Carlos II, 1681-1682," Relarioni degli Stati Europei lette al Senato degli Ambasciatori Veneti nel secolo decimosettimo. Spagna, eds. Nicolo Barozzi e Guglielmo Berchet, vol. II (Venecia: Pietro Naratovich, 1860).

Courtis, Alfred de. "Introduccion," in Lettres de Madame de Villars a Madame de Coulanges (1679-1689, ed. Marie Gigault de Bellefonds (París: Plon, 1868).

Daybell, James. "Gender, Politics and Diplomacy: Women, News and Intelligence Networks in Elizabethan England," in Diplomacy and Early Modern Culture, eds. Robyn Adams and Rossana Cox (Basingstoke: Palgrave Macmillan, 2010). https://doi.org/10.1057/9780230298125_7.

Delavaud, Louis, Le marquis de Pomponne, ambassadeur et secrétaire d'état, 1618-1699 (Paris : Plon, 1911).

Diez Canseco, Vicente, Diccionario Biográfico Universal de Mujeres Célebres, t. 3 (Madrid: Imprenta de D. José Félix Palacios, 1845).

Domínguez Ortiz, Antonio. "La crisis de Castilla en 1677-1687," en Crisis y decadencia en la España de los Austrias (Barcelona, Ariel, 1969), 195-217. 
Dubost, Jean Françoise, Marie de Médicis. La reine dévoilée (Paris: Biographie Payot, 2011).

Gigault de Bellefonds, Marie, Lettres de Madame de Villars a Madame de Coulanges (16791689) (París : Plon, 1868).

Goubert, Pierre, Le siècle de Lonis XIV (Paris : Editions de Fallois, 1996).

Hoefer, Ferdinand, Nouvelle Biographie Générale, t. 45 (Paris : Firmin-Didot, 1866).

Hufton, Olwen, "Reflections on the Role of Women in the Early Modern Court," The Court Historian 5/1 (2000): 1-13. https://doi.org/10.1179/cou.2000.5.1.001

Hugon, Alain, Au service du roi catholique: «Honorables ambassadeurs » et «divins espions 》. Répresentation diplomatiche et service secret dans les relations hispano-françaises de 1598 à 1635 (Madrid : Casa de Velázquez, 2004).

Imízcoz Beunza, José María y Arroyo Ruiz, Lara, "Redes sociales y correspondencia epistolar. Del análisis cualitativo de las relaciones personales a la reconstrucción de redes egocentradas," Redes. Revista hispana para el análisis de redes sociales 21 (2011): 98-138. https://doi.org/10.5565/rev/redes.419.

Jumel de Berneville, Marie Catherine, Relation du voyage d'Espagne (Paris : Desjonquères, 2005).

Kamen, Henry, La España de Carlos II (Madrid: Crítica, 1981).

._ "The decline of Spain: a historical myth?," Past \& Present 81 (1978): 24-50. https://doi.org/10.1093/past/81.1.24

Keller, Katrin. "Frauen-Hof-Diplomatie: Die höfische Gesellschaft als Handlungsraum von Frauen in Außenbeziehungen," Das Geschlecht der Diplomatie. Geschlechterrollen in den Außenbeziehungen vom Spätmittelalter bis zum 20. Jabrbundert, ed. Corine Bastian et al. (Köln: Böhlau, 2014), 33-50. https://doi.org/10.7788/boehlau.9783412216719.33

. - "Ladies-in-waiting at the Imperial Court of Vienna from 1550 to 1700: structures, responsibilities, and career patterns," in The Politics of Female Households. Ladies-in-waiting across Early Modern Europe, eds. Nadine Akkerman, and Birgit Houben (Leiden-Boston: Brill, 2014), 77-97. 
Labrador Arroyo, Félix. "La formación de las Etiquetas Generales de Palacio en tiempos de Felipe IV: la Junta de Etiquetas, reformas y cambio en la Casa Real," en La Casa de Borgoña: la Casa del rey de España, eds. Félix Labrador Arroyo y José Eloy Hortal Muñoz (Lovaina: Leuven University Press, 2014), 99-128. https://doi.org/10.2307/j.ctt9qdz6d.10.

Lobato, María Luisa, "Miradas de mujer. María Luisa de Orleans, esposa de Carlos II, vista por la marquesa de Villars (1679-1689)," en Teatro y poder en la época de Carlos II. Fiestas en torno a reyes y virreyes, ed. Judith Farré Vidal (MadridFrankfurt am Main-México: Iberoamericana-Vervuert-Universidad de Navarra, 2007).

López-Cordón Cortezo, María Victoria. "Las mujeres en la vida de Carlos II," en Carlos II. El rey y su entorno cortesano, ed. Luis Ribot (Madrid: CEEH, 2009).

Maura, Gabriel de, María Luisa de Orleans, reina de España. Leyenda e historia (Madrid: Saturnino Calleja, c. 1940).

._Vida y reinado de Carlos II (Madrid: Espasa-Calpe, 1954).

Michaud, Louis Gabriele, Biographie Universelle Ancienne et Moderne, vol. 48 (Paris : Michaud Éditeur, 1827).

Mignet, François Auguste, Négociations relatives à la succession d'Espagne sous Louis XIV, t. 3 (Paris : Imprimerie Royale, 1842).

Morel-Fatio, Alfred et Léonardon, Henry, Recueil des Instructions données aux ambassadeurs et ministres de France depuis les traites de Westphalie jusqu'à la Révolution Française, Espagne (Paris : Ancienne Librairie Germer Baillier et Félix Alcán éditeur, 1894).

Moser, Carl von Friedrich, L'ambassadrice et ses droits (Berlin : Étienne de Bourdeaux, 1754).

Oliván, Laura. "Lady Anne Fanshawe, ambassadress of England at the Court of Madrid (1664-1666)," in Women, Diplomacy and International Politics since 1500, eds. Glenda Sluga and Carolyn James (London: Routledge, 2015), 68-85. https://doi.org/10.4324/9781315713113-5

. - "Gender, Work and Diplomacy in Baroque Spain: The Ambassadorial Couples of the Holy Roman Empire as Arbeitspaare," Gender \& History 29/2 (2017): 423-445. https://doi.org/10.1111/1468-0424.12290 
Rabutin-Chantal, Marie de, Lettres de Madame de Sévigné da se famille et de ses amis, vol. 1 (Paris : Hachette, 1876).

Reynols, David, "International History, the Cultural Turn and the Diplomatic Twitch," Cultural and Social History 3 (2006): 5-91. https://doi.org/10.1191/1478003806cs053xx

Lynn, John, The Wars of Louis XIV, 1667-1714 (Harlow-Essex: Longman, 1999).

Louis de Rouvroy Saint-Simon., Memoires, t. I (Paris : Librairie Hachette, 1879).

Simón Palmer, María del Carmen, "El silencio en la Casa de la Reina," Lectora 13 (2007): 45-59.

Sluga, Glenda and James, Carolyn, eds., Women, Diplomacy and International Politics since 1500 (London: Routledge, 2015).

Villars, Pierre de., Mémoires de la cour d'Espagne, de 1679 à 1681 (Paris : Plon, 1893).

Volpini, Paola, "Ambasciatori, cerimoniali e informazione política: il sistema diplomatico e le sue fonti," in Nel Laboratorio della Storia, ed. María Pía Paoli (Roma: Carocci, 2013), 237-265.

Watkins, John, “Toward a New Diplomatic History of Medieval and Early Modern Europe," Journal of Medieval and Early Modern Studies 38/1 (2008): 1-14. https://doi.org/10.1215/10829636-2007-016

Wunder, Heide, He is the Sun. She is the Moon: Women in Early Modern Germany (Cambridge: Cambridge University Press, 1988).

Yun Casalilla, Bartolomé, "Del centro a la periferia: la economía española bajo Carlos II,” Studia Histórica. Historia Moderna 20 (1999): 45-75.

Zapata, María Teresa, La entrada en la Corte de María Luisa de Orleans. Arte y fiesta en el Madrid de Carlos II (Madrid: Fundación de Apoyo a la Historia del Arte Hispano 